\title{
The Financial Performance of Korean Manufacturing SMEs: Influence of Human Resources Management*
}

\author{
Umair KHAN ${ }^{1}$, Yongan ZHANG ${ }^{2}$, Madiha SALIK ${ }^{3}$
}

Received: April 29, 2020 Revised: May 31, 2020 Accepted: July 07, 2020

\begin{abstract}
The purpose of this study is to explore and empirically analyze the factors affecting the financial performance of Korean small- and medium-sized manufacturing companies, which are relatively insufficiently researched, in terms of human resource management (HRM). In particular, this study intends to examine the human resource management activities focusing on the individual influences of workers' attitudes on systems and policies as well as jobs and organizations. This study reviews previous research and discussions on the human resource management system, as well as the organization and job-related attitudes and financial performance of workers, for the formulation of two hypotheses. Among the HCCP data, the hypothesis was verified through reliability and correlation analysis and stepwise multiple regression analysis for small- and medium-sized manufacturing enterprises. The results show, firstly, that human resource systems and systems have the same effect, but there were differences in the degree of impact. Secondly, job satisfaction has a statistically significant influence on financial performance. Lastly, all worker/employee attitude determinants are statistically significant for both job satisfaction and organizational commitment. HRM, previously relatively overlooked, provided theoretical and practical implications by demonstrating the direct impact on financial performance and the impact of individual human resource management systems and policies.
\end{abstract}

Keywords: SME, Financial Performance, Non-Financial Performance, HRM, Employee Attitude

JEL Classification Code: M5. P43, L25

\section{Introduction}

*Acknowledgements: We would like to express our deepest appreciation to all those who provided us the possibility to complete this article.

*Funding: This research is supported by the Project of Beijing Municipal Commission of Education, "Research on the Driving Factors of PM2.5 Emissions and the Collaborative Emission Reduction Model in Beijing-Tianjin-Hebei", scientific research project Fund No. : SZ201510005001

${ }^{1}$ First Author and Corresponding Author. PhD Student, College of Economics and Management, Beijing University of Technology, China [Postal Address: No. 100, Pingyuan, Chaoyang District, Beijing, 100124, China] Emails: khanpk88@yahoo.com

2Professor, College of Economics and Management, Beijing University of Technology, China. Emails: bjutzhya@bjut.edu.cn

${ }^{3} \mathrm{PhD}$ Scholar, Beijing Normal University, China.

Email:salik_madiha@yahoo.com

(C) Copyright: The Author(s)

This is an Open Access article distributed under the terms of the Creative Commons Attribution Non-Commercial License (http://Creativecommons.org/licenses/by-nc/4.0/) which permits unrestricted noncommercial use, distribution, and reproduction in any medium, provided the original work is properly cited.
Human resources are the most important assets for any organization, and it is a major source of achieving competitive advantage. In an era of competitive market and globalization, determinants of business performance are key stream of study and the main interest of management. However, it seems more momentous in the current situation of the world economy facing difficult and transitional times for most of the economy participants. In these circumstances, how can the business perform? Researchers across the globe have evolved and successfully practiced certain HRM techniques in order to achieve best performance and productivity from human capital. Eventually, the performance of the enterprise is a result of a very complex and diverse collection of factors and practices. It can't be improved by one or two things, therefore companies are already doing a lot for the performance of an enterprise.

Checking can give information about which factor has real impact and influence on the performance of an 
enterprise. Innovation is vital to firm competitiveness and long-term development as well as national economic growth (Chiu \& Lin, 2019). Information could save time and reduce costs while making selection and concentration. Small- and medium-sized enterprises (SMEs) are the backbone of any economy for achieving sustainable economic and social development. They hold the major stake in the business world. The Organization for Economic Co-operation and Development (OECD, 2017) and Eurostat (2017) claimed that SMEs accounted for $95 \%$ of global businesses. The purpose of this exploratory research is to analyze factors that affect the financial performance small- and medium-sized enterprise (SME) in the manufacturing industry in Korea.

Even though HRM is a good predictor of business performance (Ali, Rehman, Ali, Yousaf, \& Zia, 2010; Bakotić, 2016; Brown \& Mitchell, 1993; Chi \& Gursoy, 2009; Guest, Michie, Conway, \& Sheehan, 2003; Huselid, 1995; Schneider, Hanges, Smith, \& Salvaggio, 2003; Sels et al., 2006; Son, 2018), SEM's HRM and financial performance has rarely studied (Chi \& Gursoy, 2009; Chun, Shin, Choi, \& Kim, 2013; Sels et al., 2006). Also, most studies analyzing HRM and performance use surveys (Ali et al., 2010; Chi \& Gursoy, 2009), not may studies use financial performance (Bakotić, 2016; Schneider et al., 2003). Generally, the mechanism of SD has been seen in the large firms. However, SMEs are also considered to engage in the practices of SD because they represent the majority of businesses around the world (Higgs \& Hill, 2019; Lee, Herold, \& Yu, 2016) and are closely linked to their customers, employees, business partners, and society (Ayuso \& Navarrete-Báez, 2018).

This research focuses on two HRM factors, one is ongoing HRM practices such as policy and system company implementation and the other is employee's attitude to job and organization, which include non-financial performance. This research analyzes the influence of HRM factors on financial performance and the mediating effect of the nonfinancial performance on employee's attitudes toward job and organization. This research focuses on the effect of each of them on HRM practices like policy and system as well as employee attitude of job and organization. The result of this study should provide managerial implications to manufacturing SMEs for their HRM management and fill the gap in the academic literature.

\section{Literature Review}

\subsection{HRM and Financial Performance}

Based on Social Exchange theory, companies try to fulfill employees' need and offer consideration and interest in exchange to develop satisfaction or commitment (Gakovic \& Tetrick, 2003; Meyer \& Allen, 1991). When employees perceive their company evaluates and compensates them fairly, they might want to continue or even contribute to activities that lead to performance improvement. Financial capital is essential for smooth running of the business operation. A high level of capital availability encourages firms to expand their service into new markets and gain competitive position, whereas a low level of financial availably could discourage firms to proceed with their operational activities (Xu \& Hitt, 2020).

In today's globalized competition, one of the most significant challenges for firms is how to attain efficiency in term of both environmental and financial performance (Klewitz \& Hansen, 2014; Lucato, Costa, \& de Oliveira Neto, 2017). Brown and Mitchell (1993) test the relation between organizational obstacle and performance outcome. Their study considered two organizational obstacles social and technical - and three types of performance outcomes - customer satisfaction, financial performance, and employee job satisfaction. As results show, different job types link different organizational obstacles. Overall, organizational obstacles negatively affect their job satisfaction. However, the effect was not significant for financial performance. Therefore, Huselid (1995) analyzes links between systems of high-performance work practices (HPWP) on firm performance. His study included two factors of HPWP - employee skills and organizational structures and employee motivation - and two financial performances - Tobin's q and gross rate of return-onassets (ROA). Also two intermediate employee outcomes - turnover and productivity - were analyzed. Results show that employee skills and organizational structure and productivity positively affect both Tobin's q and gross rate of ROA.

However, turnover has a negatively effect on Tobin's q. Guest et al. (2003) studied the relationship between HRM and performance. They measure nine areas of HR practices for HRM. However, the analysis identified a single variable that explains the high use of HRM practices [???]. Five objective and subjective performances were used - labor turnover, sales per employee in 2000, profit per employee in 2000, productivity, and financial performance. Results show high use of HRM practices decreases labor turnover and increases profit per employee in 2000, productivity, and financial performance. Sels et al. (2006) explore links among HRM intensity, voluntary turnover, productivity, the share of personnel costs in the value-added, liquidity, solvency, and profitability of small businesses. Six domains of HR each included three indicators were used as single HRM intensity. Structural equation model (SEM) results show that HRM intensity increases profitability directly, also through productivity and share of personnel costs in the value-added. Profitability increases solvency. 
Son(2018)studies therelationshipamongtransformational leadership, performance measurement systems (PMS), nonfinancial, and financial organizational performances. In his study, PMS includes justice and interaction; non-financial organizational performances include market share, customer satisfaction, quality/service level, and employee loyalty; and financial organizational performances include ROA and EVA (economic value added). Son analyzed PMS and nonfinancial organizational performances as a mediator between transformational leadership and financial organizational performances. Results show that transformational leadership does not have a direct effect on both non-financial and financial organizational performances. PMS increases nonfinancial organizational performances, however, financial organizational performances show mixed results.

H1: HRM practices (policy and system) has a positive influence on financial performance.

\subsection{Employee Attitude and Financial Performance}

Based on Interpersonal Trust theory, to accomplish the goals of communicating and trusting is important, yet, interpersonal trust is the depending effect. Interaction between relations is the effect of communication and trust, which affect goal archiving. The financial performance is usually implemented to reduce the company's operating costs and improve profit (Klewitz \& Hansen, 2014).

Huselid (1995) shows a full intermediate effect of turnover between HPWP and Tobin's q. Regression results show employee skills and organizational structures decrease turnover, and turnover decreases Tobin's q. Banker, Konstans, and Mashruwala (2000) study links among employee satisfaction, employee turnover, customer satisfaction, and two financial performance - revenue and cost. Results show that employee satisfaction and customer satisfaction increase revenue and employee turnover influences the opposite. On the contrary, employee turnover increases cost. However, employee satisfaction and customer satisfaction were not significant on cost. Revenue increases cost. They included voluntary turnover influence in their analysis, yet results were not significant. In correlation analysis, voluntary turnover and personnel costs over value-added show a negative correlation.

Banker et al. (2000) examine the relationship between employee satisfaction, customer satisfaction, revenue, and profit. Their study shows employee satisfaction increases profit, and its influence is stronger in the high competition area. Chi and Gursoy (2009) examine the relationship between employee satisfaction and customer satisfaction on financial performance. Results show both employee satisfaction and customer satisfaction increase financial performance, and customer satisfaction partially mediates between them. Chun et al. (2013) explore the relationship between corporate ethics and firm financial performance with the mediating effect of organizational commitment (OC) and organizational citizenship behavior (OCB). SEM results show internal ethics positively influence $\mathrm{OC}$, and $\mathrm{OC}$ positively influences both interpersonal $\mathrm{OCB}$ and organizational OCB. However, only organizational OCB influences positively firm financial performance and ROA.

H2: Employee attitude performance has a positive mediating influence between employee attitudes and financial performance

\subsection{SME Studies of HRM and Financial Performance}

According to the Korea Ministry of small- and mediumsized enterprise (SME) and Startups statistics, SMEs account for $99.9 \%$ of firms and $87.9 \%$ of employment number, however, they account for $37.5 \%$ of export and $51.2 \%$ of added valued in 2016. In the manufacturing industry, SME account for $99.6 \%$ of firms and $79.1 \%$ of employment. Even though SME play a big part in business and employment, due to their frail size and subordinate relation with big business. Furthermore, SMEs are closely attached to their customers, employees, business partners, and local community (Ayuso \& Navarrete-Báez, 2018; Jansson, Nilsson, Modig, \& Hed Vall, 2017) and they have less formalized business structure; therefore, SMEs' managers should try to identify and handle the issues relevant to environment, human resource management, and community and local development. SMEs are still considered vulnerable. In June 2018, OECD economic surveys evaluated Korean economy compatibility, with results showing that the Korean economy is excessively reliant on conglomerates. They suggest policy level recommendation about SMEs like foster a fair competitive environment, built dynamic reinforcement, increase transparency of business, improve regulation uncertainty, complexity and inconsistency. Also SMEs domains are to improve productivity and compatibility on their own. Studies have shown that SME's strategic (Chae, 2017; Cho \& Hwang, 2017; Kim, 2014; G. S. Park, 2014) and relational (Chung, Yoo, \& Kim, 2014) aspects influence financial performance.

Also, studies of HRM aspect showed what SMEs have been doing. Studies have showed use of diverse HR practices in SEM (Jo, 2016; Park \& Kwon, 2002; Sels et al., 2006). Eventually, all efforts are to improve performance of SMEs and also other economy participants. However, relatively few studies examined the relationship between HRM and financial performance of SME (Chi \& Gursoy, 2009; Sels et al., 2006). It helps firm to enhance ROA and significantly contributes to overall financial performance. There is 
room for additional study. So far, the impact of diverse HR practices irrespective of firm's financial performance within SME is yet to be studied, as does the mediating effect of the employee attitude toward job and organization on firm's financial performance.

This exploratory research is to analyze antecedents of financial performance of manufacturing SME in Korea. This research focuses on two HRM factors, one are the ongoing HRM practices such as policy and system company implementation, and the other is employee's attitude toward job and organization. As the literature shows, most studies analyzed the influence of HRM practices as bundle, this research analyzes the influence of HRM practices and system separately on financial performance. Also, the literature shows there is room for studying the mediating effect of the employee attitude performance; this research analyzes the mediating effect of the employee attitude performance between employee's attitudes toward job and organization on financial performance.

\section{Research Methodology}

\subsection{Research Model}

Based on the literature review, this research focuses on HRM aspects into two-part, one is organizational attributes such as firm characteristics and on-going HRM practices such as policy and system of the company and the other is employee's personal attribute such as demographic characteristics and employee attitude job and organization. The research model is summarized in Figure 1. This research includes three relationships among factors. The first factor is about the company. This includes the influence of firm characteristics and ongoing HRM policy and system on financial performance. Financial performance includes profitability as ROA (return on assets) and growth as NPGR (net profit growth rate). The second factor is the influence of employee results on financial performance. Employee results are JS (job satisfaction) and OC (organizational commitment). The third factor is the influence of employee demographic and employee's attitude toward job and organization on employee results.

\subsection{Research Measurement}

Data for this research is from the 6th wave (2015) data of the Human Capital Corporate Panel (HCCP) issued by the Korea Research Institute for Vocational Education \& Training (KRIVET). The 6th HCCP includes 467 companies totaling 10,069 employees. This research focuses on manufacturing SMEs run by their owners. To implement or adjust quickly for their HRM management, selection and concentration with a view to save time and money, managerial support is needed from the top, therefore only the full-ownership management is included. The research includes 99 companies with a total of 2,126 employees.

The organizational attribute includes firm characteristics and ongoing HRM practices such as policy and system of the company. Firm characteristics include industry sectors (KSIC_2digit: 25 industry is included), which are coded as dummy variables in the analysis, firm type (KCSPI, KOSDAQ, etc.), coded as dummy variables, and business year. And dept. ratio (total dept. /total equity*100). Ongoing HRM-related practice is measured whether the company implements specific HR-related practice/system or not. This study includes nine practice/system, whether the company does HRD plan, does job analysis, gives evaluation feedback, works five days per week, shares a core HR concept, uses an HR information system, has a retirement policy, has retirement support policy, or has a labor representative group. Financial results cover profitability and growth of the company, ROA (net income/total asset*100), and NPGR (this year net income/last year net income*100). Organization data is measured by a questionnaire survey completed by the person in charge of HRM in each company, and financial data is from KIS value.

Employee's attributes include demographic characteristics and employee attitude on job and organization. Demographic characteristics are measured with gender (male, female), age by zone $(10 \mathrm{~s}, 20 \mathrm{~s}, 30 \mathrm{~s}, 40 \mathrm{~s}$, over 50s), education by graduation criteria (high school, college, university, graduate), position by employment contract (contract, permanent), rank (staff, manager) and area (work in manufacturing field -blue, in office white). Employee attitudes include four variables HR compliment, communication, trust, and stress. Employee results include two variables - job satisfaction and organizational commitment. Employee attitudes and results are measured by a questionnaire survey sent to employees, and variables are calculated as mean. Also, this study includes liability analysis with Cronbach's alpha based on standardized items.

HR compliment is measured with four survey items, compliments such as - superb HR, have clear HRD vision, emphasize the importance of HR, and seek a diverse HRD training method. Cronbach's alpha of HR compliment is 0.869. Communication is measured with three survey items, such as to inform the detailed company circumstance to an employee, to suggest opinion freely to the supervisor, and to communicate well with a coworker. Cronbach's alpha of Communication is 0.832 . Trust is measured with three survey items, such as trust each other in the workplace, fair evaluation and compensation, and can trust and follow company management. Cronbach's alpha Trust is 0.775 . Stress is measured with three survey items, such as feel unfair about current development and promotion opportunity, feel 
suspended and tired due to job, and increase of tension at work. Cronbach's alpha of Stress is 0.716 . Job satisfaction is measured with four survey items, such as satisfied with work, compensation, human relationship in the job, and overall job.

Cronbach's alpha of job satisfaction is 0.737 . Organizational commitment is measured with four survey items, such as will consider turnover when a better condition is offered, feel like company problem as mine, will lose a lot when leaving the company, and worth being loyal to the company. Cronbach's alpha of organizational commitment is 0.694 .

\subsection{Research Sample}

Table 1 summarize characteristics of 99 firms. 25 industry (2digit KSIC) is included and category are 10 (food products, 4 firms), 11 (beverages, 1 firm), 13 (textiles, except apparel,

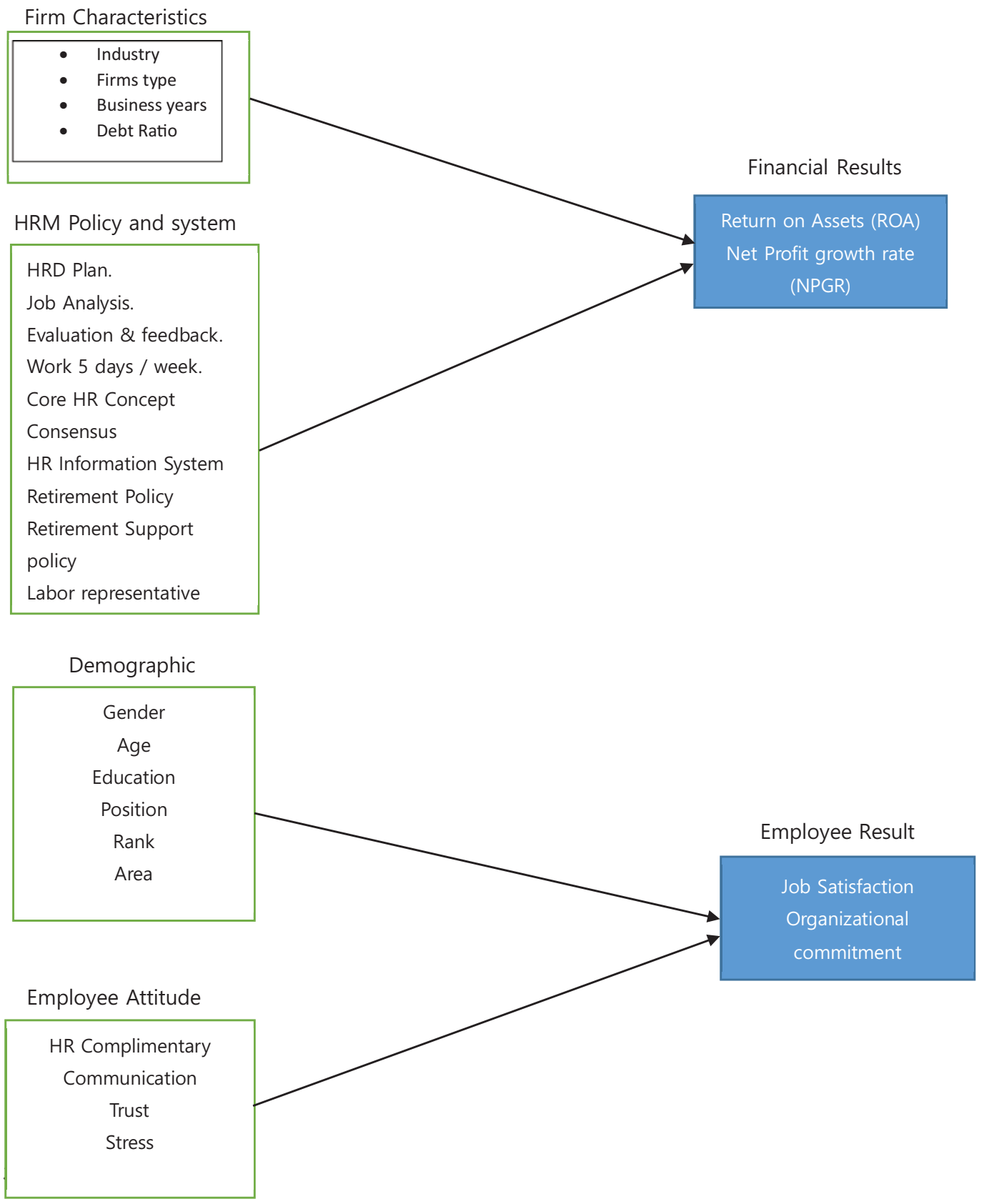

Figure 1: Research Model 
6 firms), 14 (wearing apparel, clothing accessories and fur articles, 1 firm), 15 (leather, luggage and footwear, 2 firms), 16 (wood and of products of wood and cork: except furniture, 1 firm), 17 (pulp, paper and paper products, 1 firm), 18 (printing and reproduction of recorded media, 1 firm), 19 (coke, briquettes and refined petroleum products, 1 firm), 20 (chemicals and chemical products; except pharmaceuticals and medicinal chemicals, 5 firms), 21 (pharmaceuticals, medicinal chemical and botanical products, 1 firm), 22 (rubber and plastics products, 7 firms), 23 (other nonmetallic mineral, 4 firms), 24 (basic metals, 8 firms), 25 (fabricated metal products, except machinery and furniture, 3 firms), 26 (electronic components, computer; visual, sounding and communication equipment, 19 firms), 27 (medical, precision and optical instruments, watches and clocks, 1 firm), 28 (electrical equipment, 7 firms), 29 (machinery and equipment, 9 firms), 30 (motor vehicles, trailers and semitrailers, 10 firms), 31 (other transport equipment, 2 firms), 41 (general construction, 1 firm), 42 (specialized construction activities, 2 firms), 46 (Wholesale trade on own account or on a fee or contract basis, 1 firm), 72 (Architectural, engineering and other scientific technical services, 1 firm).

Table 1: Firm Sample Characteristics ( $\mathrm{N}=99)$

\begin{tabular}{|c|c|c|c|c|c|c|c|c|}
\hline \multirow{5}{*}{$\begin{array}{l}\text { Industry } \\
\text { Code } \\
\text { (N) }\end{array}$} & \multicolumn{4}{|c|}{ Characteristics } & HRM Policy \& System & & $\mathbf{N}$ & $\%$ \\
\hline & \multirow{4}{*}{\multicolumn{4}{|c|}{$\begin{array}{c}\text { 10(4), 11(1), 13(6), 14(1), 15(2). 16(1), 17(1). 18(1), } \\
\begin{array}{c}\text { 19(1), 20(5), 21(1), 22(7), 23(4), 24(8), 25(3), 26(19), } \\
27(1), \quad 28(7), \quad 29(9), 30(10), 31(2) . \\
46(1), 72(1)\end{array}\end{array}$}} & HRD Plan & $\begin{array}{l}\text { NO } \\
\text { Yes }\end{array}$ & $\begin{array}{l}43 \\
56\end{array}$ & $\begin{array}{l}43.4 \\
56.6\end{array}$ \\
\hline & & & & & Job Analysis & $\begin{array}{l}\text { NO } \\
\text { Yes }\end{array}$ & $\begin{array}{l}64 \\
35\end{array}$ & $\begin{array}{l}64.6 \\
35.4\end{array}$ \\
\hline & & & & & Evaluation Feedback & NO & 69 & 69.7 \\
\hline & & & & & & Yes & 30 & 30.3 \\
\hline \multicolumn{2}{|c|}{ Characteristics } & \multicolumn{2}{|c|}{$\mathbf{N}$} & $\%$ & Work-5-days-a-week & $\begin{array}{l}\text { NO } \\
\text { Yes }\end{array}$ & $\begin{array}{c}1 \\
98 \\
\end{array}$ & $\begin{array}{c}10 \\
99.0 \\
\end{array}$ \\
\hline \multirow{4}{*}{ Firm Type } & KCSPI & & & 20.2 & \multirow{2}{*}{$\begin{array}{l}\text { Core HR Concept } \\
\text { Consensus }\end{array}$} & No & 81 & 81.5 \\
\hline & KOSDAQ & \multicolumn{2}{|c|}{31} & 31.3 & & Yes & 18 & 18.2 \\
\hline & ETC & \multicolumn{2}{|c|}{48} & 48.5 & HR Information System & $\begin{array}{l}\text { No } \\
\text { Yes }\end{array}$ & $\begin{array}{l}13 \\
86\end{array}$ & $\begin{array}{l}13.1 \\
86.9\end{array}$ \\
\hline & Big Year & Dept Ratio & RAO & NPGR & Retirement Policy & $\begin{array}{l}\text { No } \\
\text { Yes }\end{array}$ & $\begin{array}{c}2 \\
97\end{array}$ & $\begin{array}{c}2.0 \\
98.0\end{array}$ \\
\hline Mean & 35.5 & 218.9 & 5.5 & 66.0 & \begin{tabular}{|l|} 
Retirement Support \\
Policy
\end{tabular} & $\begin{array}{l}\text { No } \\
\text { Yes }\end{array}$ & $\begin{array}{c}94 \\
5\end{array}$ & $\begin{array}{c}94.9 \\
5.1\end{array}$ \\
\hline Middle & 32 & 112.7 & 4.5 & 29.8 & \begin{tabular}{|l|} 
Employee \\
Representative Group
\end{tabular} & $\begin{array}{l}\text { No } \\
\text { Yes }\end{array}$ & $\begin{array}{c}5 \\
94\end{array}$ & $\begin{array}{c}5.1 \\
94.9\end{array}$ \\
\hline Minimum & 10 & 3.0 & 31.1 & 98.8 & & & & \\
\hline Maximum & 80 & 13266.6 & 32.1 & 545.1 & & & & \\
\hline S.D & 15.9 & 480.1 & 9.4 & 130.3 & & & & \\
\hline Variance & 251.9 & 23023.5 & 88.9 & 16682.2 & & & & \\
\hline
\end{tabular}

Note: Industry(KSIC 2digit: 10-food products, 11-beverages, 13-textiles, except apparel, 14-wearing apparel, clothing accessories and fur articles, 15-leather, luggage and footwear, 16-wood and of products of wood and corky except furniture, 17-pulp, paper and paper products, 18-Printing and reproduction of recorded media, 19-coke, briquettes and refined petroleum products, 20-chemicals and chemical products: except pharmaceuticals and medicinal chemicals, 21-pharmaceuticals, medicinal chemical and botanical products, 22-rubber and plastics products, 23-other non-metallic mineral products, 24-basic metals, 25-fabricated metal products, except machinery and furniture. 26-electronic components, computer: visual, sounding and communication equipment, 27-medical, precision and optical instruments, watches and clocks, 28-electrical equipment, 29-other machinery and equipment, 30-motor vehicles, trailers and semitrailers, 31-other transport equipment, 41-general construction, 42-specialized construction activities, 46-wholesale trade on own account or on a fee or contract basis, 72-architectural, engineering and other scientific technical services), Firm Type (KCSPI, KOSDAQ. Etc. =external audit and general), Biz year (Business Year). 
As for firm type, 20 (20.2\%) KCSPI, 31 (31.3\%) KOSDAQ and 48 (48.5\%), which include external audit and general company. Industry and firm types are coded as dummy in later regression analysis. Mean years of business year is 35.5 and mean $218.9 \%$ of dep't, ratio. For financial performance, mean of ROA $5.5 \%$ and mean of NPGR is $66.0 \%$. Table 1 also includes nine HR practices, whether the company operates such a policy and system. First, $56(56.6 \%)$ do HRD plan, yet 43 (43.4\%) do not. Second, 35 (35.4\%) do job analysis, yet $64(64.6 \%)$ do not. Third, $30(30.3 \%)$ give evaluation feedback, however, $69(69.7 \%)$ do not. Forth, 98 $(99 \%)$ work 5-day week and only $1(1 \%)$ do not. Fifth, 18 (18.2\%) share core HR concept, yet $81(81.8 \%)$ do not. Sixth, $86(86.9 \%)$ use the HR information system, yet 13 (13.1\%) do no. Seventh, 97 (98\%) have retirement policy, however, 2 (2\%) do not. Eighth, 5 (5.1\%) have retirement support policy, yet 94 (94.9\%) do not. Finally, ninth, 94 (94.9\%) have labor representative groups, yet $5(5.1 \%)$ do not. Four out of nine HR practices showed inclined data like 5-day-a-week work, retirement policy, and retirement support policy and employee representative group. Therefore, in later analysis, these HR practice variables were excluded from correlation and regression analysis.

Table 2 summarizes 2,126 employees' characteristics, employee attitude and employee result. First employees characteristics, and for gender, male are $1,716(80.7 \%)$ and female are 410 (19.3). As for age of employees are 310 (14.6\%) teenage, $784(37 \%) 20 \mathrm{~s}, 700(33 \%) 30$ s, $312(14.7 \%)$ $40 \mathrm{~s}$ and $13(0.6 \%)$ over 50s. Education of employee is 869 (40.9\%) high school graduation, 428 (21.1\%) college, 770 (36.2\%) university and $59(2.1 \%)$ graduate school. Position as whether employment contract is a contract or permanent, $45(2.1 \%)$ are contract and $2081(97.9 \%)$ are permanent. As for rank, 763 (35.9\%) staff and 1,363 (64.1\%) manager. And as for area, $1,092(51.4 \%)$ working in the manufacturing field and 1,034 (48.6\%) in office. Second employee attitude and employee result, mean of variable are HR compliment (3.12), Communication (3.23), Trust (3.31), Stress (3.00), Job satisfaction (3.40), and Organizational commitment (3.15).

Table 2: Employee Sample Characteristics

\begin{tabular}{|c|c|c|c|c|c|c|c|}
\hline \multicolumn{2}{|c|}{ Demographic } & $\mathbf{N}$ & $\%$ & & employee attitude & & \\
\hline \multirow{2}{*}{ Gender } & Male & 1716 & 80.7 & variable & mean & S.D. & mid. \\
\hline & Female & 410 & 19.3 & HR com. & 3.12 & 0.90 & 3.00 \\
\hline \multirow{4}{*}{ Age } & $10 \mathrm{~s}$ & 310 & 14.6 & & & & \\
\hline & $20 s$ & 784 & 37.0 & \multirow{2}{*}{ Com. } & \multirow{2}{*}{3.23} & \multirow{2}{*}{0.76} & \multirow{2}{*}{3.33} \\
\hline & $30 \mathrm{~s}$ & 700 & 33.0 & & & & \\
\hline & $40 s$ & 312 & 14.7 & Trust & 3.31 & 0.73 & 3.33 \\
\hline \multirow{5}{*}{ Education } & over 50s & 13 & 0.6 & \multirow{3}{*}{ Stress } & \multirow{3}{*}{3.00} & \multirow{3}{*}{0.63} & \multirow{3}{*}{3.00} \\
\hline & High & 869 & 40.9 & & & & \\
\hline & College & 428 & 21.1 & & & & \\
\hline & University & 770 & 36.2 & & employee res & & \\
\hline & Graduate & 59 & 2.8 & variable & mean & S.D. & mid. \\
\hline \multirow[t]{2}{*}{ Position } & Contract & 45 & 2.1 & \multirow{2}{*}{ JS } & \multirow{2}{*}{3.40} & \multirow{2}{*}{0.71} & \multirow{2}{*}{3.50} \\
\hline & Permanent & 2081 & 97.9 & & & & \\
\hline \multirow[t]{2}{*}{ Rank } & Staff & 763 & 35.9 & \multirow{4}{*}{$\mathrm{OC}$} & \multirow{4}{*}{3.15} & \multirow{4}{*}{0.49} & \multirow{4}{*}{3.25} \\
\hline & Manager & 1363 & 64.1 & & & & \\
\hline \multirow{2}{*}{ Area } & White & 1092 & 51.4 & & & & \\
\hline & Blue & 1034 & 48.6 & & & & \\
\hline
\end{tabular}

Note: HR compliment (Com.) Communication (Com.) Job satisfaction (JS) Organizational commitment (OC) 


\section{Statistical Analysis Results}

\subsection{Regression Analysis of Profitability and Growth}

Before regression analysis, this study analyzes the correlation among financial results and variables, the results are summarized in Table 3. The highest correlation was between ROA and NPGR, which was 0.62 . To verify antecedent of financial performance, this study used a stepwise multiple regression analysis. First, in model 1(M1), firm characteristics are analyzed, industry, firm type, business year and dep't ratio. Second, in model 2(M2) add nine HR practices of the company including policy and system, HRD plan, job analysis, evaluation feedback, core HR concept consensus, human information system. Third, in model 3(M3) add employee attitude results are added, job satisfaction and organizational commitment. Results of regression analysis are summarized in Table 4. And all $\mathrm{T}$ (tolerance) results showed lower than 1.0 and all VIF results showed lower than 10.0 which mean multicollinearity is not a problem in this study.

First for ROA, explanation rate (ad. R) Increased 13.2\% for M1, $17.1 \%$ for M2 and $17.6 \%$ for M3. This implies HR practices explain more than firm characteristic and also even though employee attitudes influence little still its influence is significant. And all $\mathrm{T}$ (tolerance) results showed lower than 1.0 and all VIF results showed lower than 10.0, which mean multicollinearity is not a problem in this study.

For control variables, industry dummy variables were deleted during stepwise multiple regression analysis. Both firm type dummy1 (-.247) and dummy2 (-.063) were significant, which imply KOSPI and KOSDAQ firms show lower ROA. Business year (-.106) and Dep’t ratio (-.242) were also significant, which imply longer the business year lower the ROA and higher the dept. ratio lower the ROA. For HR practices, among five HR practices four give significant influence on ROA and one was not significant. Among four, three were negative and one was positive. HRD plan (-.074), core HR concept consensus (-.147) and HR information system (-.092) gave negative significant influence on ROA. Maybe HRD plan, core HR concept consensus and HR Information system in not delivered constructively to employee or execute properly. Or there can be black box between relations therefore more in depth study is needed.

Job analysis (.087) shows a positive effect. Maybe employees know what their job includes or the company consistently motivates employees to work. However, these mixed results of HR practice influence suggest that a company needs to consider the effect of their HR practices more economically due to its cost and effect. For employee results, even if it's not large, job satisfaction (.083) has a positive significant influence on ROA. This result implies that satisfied employee increases ROA, therefore antecedent of job satisfaction need to be analysis. To do that, this study provides an additional analysis of determinants of job satisfaction, and results are summarized in Table 6. Second, for NPGR, explanation rate (ad. $\mathrm{R}^{2}$ ) is $7.7 \%$ for $\mathrm{M} 1,13.5 \%$ for M2 and $15.0 \%$ for M3. This implies HR practices explain more than firm characteristics and also even though employee attitudes influence little still its influence is significant.

Table 3: Correlation Results of Financial Results

\begin{tabular}{|c|c|c|c|c|c|c|c|c|c|c|c|c|c|c|}
\hline & Mean & S.D & A & B & C & D & $E$ & $F$ & G & H & $I$ & $\mathbf{J}$ & $\mathrm{K}$ & $L$ \\
\hline$A$ & 1.961 & .624 & 1 & & & & & & & & & & & \\
\hline B & 2.150 & .795 & .003 & 1 & & & & & & & & & & \\
\hline C & 36.802 & 15.797 & -.069 & -543 & 1 & & & & & & & & & \\
\hline $\mathrm{D}$ & 218.893 & 480.139 & -.027 & .257 & -.048 & 1 & & & & & & & & \\
\hline$E$ & .64 & .481 & .368 & -.153 & .050 & -.062 & 1 & & & & & & & \\
\hline $\mathrm{F}$ & .40 & .490 & -.038 & -.052 & .049 & -.054 & .175 & 1 & & & & & & \\
\hline$G$ & .39 & .487 & .170 & -.196 & .090 & -.108 & .264 & .312 & 1 & & & & & \\
\hline $\mathrm{H}$ & .25 & .433 & -.128 & -.131 & -.167 & -.026 & -.048 & .290 & .086 & 1 & & & & \\
\hline 1 & .87 & .340 & .364 & -.305 & .069 & -.187 & .424 & -.027 & .118 & -.014 & 1 & & & \\
\hline $\mathrm{J}$ & 3.398 & .706 & .057 & $-/ 116$ & .067 & -.070 & .057 & .077 & .137 & .020 & .029 & 1 & & \\
\hline $\mathrm{K}$ & 3.154 & .491 & .032 & -.038 & .002 & .016 & .060 & -.077 & .008 & .040 & .067 & .303 & 1 & \\
\hline $\mathrm{L}$ & 5.549 & 9.431 & .290 & .139 & -.216 & -.209 & -.128 & -.094 & -.010 & -.058 & -.143 & .093 & .009 & 1 \\
\hline$M$ & 5.417 & 17.208 & .026 & .078 & .179 & -.27 & -.132 & -.005 & -.145 & -.182 & -.161 & .114 & .026 & .620 \\
\hline
\end{tabular}

Note: $p<0.05, Z: p<0.01$. A-Industry. B-Firm type. C-Business year. D-Debt ratio. E-HRD plan, F-Job analysis, G-evaluation feedback. $\mathrm{H}$-core human resource concept. I-human system. J-job satisfaction. K-organizational commitment. L-ROA, M-NPGR 
Table 4: Regression Result of Profitability and Growth

\begin{tabular}{|c|c|c|c|c|c|c|c|c|c|c|}
\hline \multirow{3}{*}{ St. $\beta(t)$} & \multicolumn{5}{|c|}{ Profitability (ROA) } & \multicolumn{5}{|c|}{ Growth (NPGR) } \\
\hline & \multirow[t]{2}{*}{ M1 } & \multirow[t]{2}{*}{ M2 } & \multicolumn{3}{|c|}{ M3 } & \multirow[b]{2}{*}{ M1 } & \multirow[b]{2}{*}{ M2 } & \multirow[b]{2}{*}{ St. $\beta(t)$} & \multirow[b]{2}{*}{$T$} & \multirow[b]{2}{*}{ VIF } \\
\hline & & & St. $\beta(t)$ & $T$ & VIF & & & & & \\
\hline $\begin{array}{l}\text { Firm Type } \\
\text { Dummy2 }\end{array}$ & $\begin{array}{l}-231^{*} \\
(7.880)\end{array}$ & $\begin{array}{c}.185^{*} \\
(-5.983)\end{array}$ & $\begin{array}{c}-.247^{*} \\
(8.280)\end{array}$ & .483 & 2.072 & $\begin{array}{c}-125: \\
(-4.110)\end{array}$ & $\begin{array}{c}-.226: \\
(-7.110)\end{array}$ & $\begin{array}{l}-2.253: \\
(-7.457)\end{array}$ & .453 & 2.209 \\
\hline $\begin{array}{l}\text { Firm Type Dummy } \\
2\end{array}$ & $\begin{array}{c}0.59^{*} \\
(2.379) \\
\end{array}$ & $\begin{array}{l}.065^{*} \\
(2.593) \\
\end{array}$ & \begin{tabular}{|c|}
$-.063^{*}$ \\
$(-2.506)$ \\
\end{tabular} & .692 & 1.446 & $\begin{array}{c}.162: \\
(6.566) \\
\end{array}$ & \begin{tabular}{|l|}
$-.172:$ \\
$(-6.566)$ \\
\end{tabular} & $\begin{array}{l}-.175: \\
(-6.730) \\
\end{array}$ & .666 & 1.502 \\
\hline $\begin{array}{l}\text { Business } \\
\text { Year }\end{array}$ & $\begin{array}{c}-0.56^{*} \\
(-2.097)\end{array}$ & $\begin{array}{c}-.104^{*} \\
(-3.874)\end{array}$ & $\begin{array}{c}-.106^{*} \\
(-3.931)\end{array}$ & .598 & 1.672 & $\begin{array}{c}.292: \\
(10.488)\end{array}$ & $\begin{array}{c}.237: \\
(8.573)\end{array}$ & $\begin{array}{c}.234: \\
(8.541)\end{array}$ & .599 & 1.669 \\
\hline Dept ratio & $\begin{array}{c}-.229^{*} \\
(-10.226) \\
\end{array}$ & $\begin{array}{c}-.246: \\
(-11.174) \\
\end{array}$ & \begin{tabular}{|c|}
$-.242:$ \\
$(10.969)$ \\
\end{tabular} & .886 & 1.129 & $\begin{array}{c}-.077: \\
(-3.317) \\
\end{array}$ & \begin{tabular}{|l|}
$-.103:$ \\
$(-4.493)$ \\
\end{tabular} & $\begin{array}{c}-.097: \\
(-4.280) \\
\end{array}$ & .876 & 1.142 \\
\hline HRD Plan & & \begin{tabular}{c|}
$-.073:$ \\
$(-3.025)$ \\
\end{tabular} & \begin{tabular}{|c|}
$-.074:$ \\
$(-3.060)$ \\
\end{tabular} & .741 & 1.350 & & \begin{tabular}{|c|}
$-.066:$ \\
$(-2.653)$ \\
\end{tabular} & $\begin{array}{c}-.067: \\
(-2.717) \\
\end{array}$ & .738 & 1.355 \\
\hline Job Analysis & & $\begin{array}{l}.087: \\
(3.664)\end{array}$ & $\begin{array}{c}-.087: \\
(3.646)\end{array}$ & .758 & 1.319 & & $\begin{array}{c}.090: \\
(3.700)\end{array}$ & $\begin{array}{c}.091: \\
(3.732)\end{array}$ & .765 & 1.307 \\
\hline $\begin{array}{l}\text { Evaluation } \\
\text { feedback }\end{array}$ & & $\begin{array}{l}-.010 \\
(-.452) \\
\end{array}$ & $\begin{array}{l}-.018 \\
(-.807) \\
\end{array}$ & .823 & 1.215 & & \begin{tabular}{|c|}
$-.125:$ \\
$(-5.300)$ \\
\end{tabular} & $\begin{array}{c}-137: \\
(-5.855) \\
\end{array}$ & 820 & 1.219 \\
\hline $\begin{array}{l}\text { Core-HR } \\
\text { Concept } \\
\text { Consensus }\end{array}$ & & $\begin{array}{c}-.145: \\
(-6.440)\end{array}$ & $\begin{array}{l}-.147: \\
(-6.537)\end{array}$ & .854 & 1.171 & & $\begin{array}{l}-.188: \\
(-8.131)\end{array}$ & $\begin{array}{c}-.194: \\
(-8.451)\end{array}$ & .854 & 1.171 \\
\hline $\begin{array}{l}\text { HR. } \\
\text { Information } \\
\text { System }\end{array}$ & & $\begin{array}{c}-.095: \\
(-3.397)\end{array}$ & $\begin{array}{c}-.092: \\
(-3.678)\end{array}$ & .693 & 1.443 & & $\begin{array}{c}-.045 \\
(-1.741)\end{array}$ & $\begin{array}{c}-.041 \\
(-1.592)\end{array}$ & .694 & 1.440 \\
\hline Job Satisfaction & & & $\begin{array}{l}.083: \\
(3.747)\end{array}$ & .888 & 1.126 & & & $\begin{array}{c}.124: \\
(5.512) \\
\end{array}$ & .887 & 1.128 \\
\hline $\begin{array}{l}\text { Organizational } \\
\text { Commitment }\end{array}$ & & & $\begin{array}{l}-.004 \\
(-.173)\end{array}$ & .887 & 1.128 & & & $\begin{array}{l}.011 \\
(.504)\end{array}$ & .887 & 1.128 \\
\hline Ad. $R^{2}$ & .132 & .171 & \multicolumn{3}{|c|}{.176} & .077 & .135 & & & \\
\hline $\mathrm{F}$ & 74.001:* & 44.980:* & \multicolumn{3}{|c|}{$38.143^{* *}$} & 40.379:* & \multicolumn{2}{|c|}{$33.647^{* *}$} & \multicolumn{2}{|c|}{.150} \\
\hline & & & & & & \multicolumn{5}{|c|}{$31.265:^{*}$} \\
\hline
\end{tabular}

For control variables, industry dummy variables were deleted during stepwise multiple regression analysis. Both firm type dummy1 (-.235) and dummy2 (.-175) were negative, which implies KOSPI and KOSDAQ firms show lower NPGR. Business year (.234) and dept. ratio (-.097) were also significant, which implies the longer the business year, the higher the NPGR; the higher the dep't ratio, the lower the NPGR. For HR practices, among five HR practices, three were significantly negative, one was significantly positive and one was not significant. HRD plan (-.067), Evaluation feedback (.137) and HR concept consensus (-.194) give negative affect. Maybe representative group is not supportive to firm. May be HRD plan, evaluation feedback and core
HR concept consensus delivered constructively to employee or execute properly. Or there can be black box between relations, therefore, more in depth study is needed. Job analysis (.073) has positive affect. Maybe job analysis gives clear understanding of what to do to increase motivation and efficiency. These mixed results of HR practice influence suggest that a company needs to consider the effect of their HR practices more economically due to its cost and effect.

For employee results, job satisfaction (.124) has a positive significant influence on NPGR. This result implies that satisfied employee increases NPGR, therefore antecedents of job satisfaction need to be analysis. As for H1, which hypothesizes HRM practices (policy and system) have 
positive influence on financial performance, results show mixed results from variables and on financial performances. Therefore, $\mathrm{H} 1$ is partially supported or rejected..

\subsection{Regression Analysis of Job Satisfaction and Organizational Commitment}

As shown in Table 4, job satisfaction increases both ROA (.083) and NPGR (.124), therefore, to improve ROA and NPGR, job satisfaction of employees needs to be managed. Then, what influences job satisfaction? Based on the literature review, this study considered two employee factors, demographics and attitude toward job and organization. Even organizational commitment were not significant in both ROA and NPGR; this study included organizational commitment based on literature review. Before regression analysis, this study analyzed the correlation among financial results and variables; the results are summarized in Table 5. The highest correlation was between communication and trust, which was 0.80 .

This study used a stepwise regression analysis. First, in model 1(M1), demographic are analyze; gender, age, education, position, rank, and area. Second, model 2(M2) adds four attitudes toward job and organization, HR compliment, communication, trust, and stress. Results are summarized in Table 6. An explanation rate increase from M1 (2.8\%) to M2 (36.5\%) for job satisfaction and also the organizational commitment from M1 (5.8\%) to M2 (22.4\%). It implies that understanding employee's attitude toward job and organization is critical to managing job satisfaction and organizational commitment. And all $\mathrm{T}$ (tolerance) results showed lower than 1.0 and all VIF results showed lower than 10.0 , which means multicollinearity is not a problem in this study. As for job satisfaction, among six demographics two are significant, rank (.056) and area (-.058). This means that the manager's job satisfaction is higher than staff and job satisfaction of employee, and working in manufacturing is higher than in the office.

All attitude variables show a significant influence on job satisfaction. From top down influence is trust (.308), HR compliment (.164), communication (.132) and stress (-.116), which is only negative influence shown. As for organizational commitment, among six demographic three are significant, gender (-.096), position (.060) and rank (.093). This means that male employee's organizational commitment is higher than female, permanent position's organizational commitment is higher than the contract and manager's organizational commitment is higher than staff. Also, all attitude variables show a significant positive influence on organizational commitment. From top down influence is trust (.257), stress (.213), communication (.101) and HR compliment (.093).

$\mathrm{H} 2$, which hypothesizes a positive mediating influence of employee attitude performance between employee attitudes on financial performance, shows mixed results from ROA to NPGR and job satisfaction and organizational commitment. Therefore, $\mathrm{H} 2$ is partially supported or rejected.

\section{Conclusion}

This study analyzes the determinants of the financial performance of manufacturing SME in Korea. In particular,

Table 5: Correlation Results of Employee Result

\begin{tabular}{|c|c|c|c|c|c|c|c|c|c|c|c|c|c|}
\hline & Mean & S.D & A & B & C & D & E & F & G & H & I & J & K \\
\hline A & 1.96 & .40 & 1 & & & & & & & & & & \\
\hline B & 2.50 & .94 & $.04^{*}$ & 1 & & & & & & & & & \\
\hline C & 2.01 & .94 & -.18 & $-30 ;$ & 1 & & & & & & & & \\
\hline D & .98 & .14 & -.08 & $.09 ;$ & $-.11:$ & 1 & & & & & & & \\
\hline E & 1.64 & .48 & -.33 & $-.23:$ & $.28:$ & $-.12:$ & 1 & & & & & & \\
\hline F & 1.49 & .50 & -.04 & $-.26:$ & -.67 & $-.10:$ & $.32:$ & 1 & & & & & \\
\hline G & 3.12 & .89 & $.12^{* *}$ & $-.03:$ & -.15 & -.12 & .13 & $.15:$ & 1 & & & & \\
\hline H & 3.23 & .76 & $-.14^{*}$ & $-.02:$ & -.10 & -.00 & -.10 & $.10:$ & $.65:$ & 1 & & & \\
\hline I & 3.31 & .73 & $.08:$ & $-.03:$ & $.10^{*}$ & -.02 & .06 & .09 & $.69:$ & $-.80:$ & 1 & & \\
\hline J & 3.00 & .63 & $-.07:$ & $-.03:$ & .03 & -.03 & .03 & .01 & $-.23:$ & .21 & .24 & 1 & \\
\hline K & 3.40 & .71 & $-.09:$ & $-.01:$ & $.11:$ & .03 & $.13:$ & -.13 & $.50:$ & .52 & $.56^{* *}$ & $.25^{*}$ & 1 \\
\hline L & 3.15 & .49 & $-.18:$ & $.00:$ & $-.14:$ & $-.08:$ & $-.19:$ & -.12 & $-.31:$ & .35 & $.37^{* *}$ & .11 & $.30:$ \\
\hline
\end{tabular}

A-gender, R-age, C—education, 1)—position, E—rank, F-area, O-human resource compliment. H-communication, I-trust. J-stress, K-job satisfaction, L-organizational commitment. 
this study focuses on HRM, the company's HRM practice including policy and system and employee's attitude toward job and organization. Analysis results could summarize into three parts. First, for the financial results, there were some similar and opposite influence of HRM practices to ROA and NPGR. As for ROA, there were one positive and three negative influences of HRM practices. And for NPGR, there were one positive and three negative influences of HRM practices. Therefore, to increase financial performance, managers need to implement with prudence. Second, job satisfaction has a statistically significant influence on both financial performances. Therefore, to increase profitability and growth of the company, employee attitude needs to be considered. Third, all four employee attitude determinants were statistically significant for employee attitude results. Therefore, improving job satisfaction and organizational commitment managing employee recognition is needed.

Based on the analysis results summarized above, three implications for management are suggested to improve financial performance. First, to improve ROA, management needs to consider four HR practices and employee's job satisfaction. One out of four HR practices has a positive influence: job analysis. However, three out of four have a negative influence: HRD plan, core HR concept consensus, and HR information system. Therefore, managers need to consider the effect of each HR practice and implement with prudence. Also, job satisfaction has a minor still positive influence on ROA. Therefore, employee's satisfaction toward work, compensation, human relationship in job and overall job need further managerial interest.

Second, to improve NPGR, management needs to consider four HR practices and employee's job satisfaction. One out of five has a positive affect: job analysis. Three out of five have a negative affect: HRD plan, evaluation feedback, and core HR concept consensus. Therefore, managers need to consider the effect of each HR practice and implement with prudence. Also, job satisfaction has a positive influence on NPGR. Therefore, management needs to understand what influences employee results.

Table 6: Regression Result of Job Satisfaction and Organizational Commitment

\begin{tabular}{|c|c|c|c|c|c|c|c|c|}
\hline \multirow{3}{*}{ St. $\beta(t)$} & \multicolumn{4}{|c|}{ Job Satisfaction } & \multirow{2}{*}{\multicolumn{4}{|c|}{$\frac{\text { Organizational Commitment }}{\mathrm{M} 2}$}} \\
\hline & \multirow{2}{*}{ M1 } & \multicolumn{3}{|c|}{ M2 } & & & & \\
\hline & & St. $\beta(t)$ & Tolerance & VIF & M1 & St. $\beta(t)$ & Tolerance & VIF \\
\hline Gender & $\begin{array}{l}-057^{*} \\
(2.460)\end{array}$ & $\begin{array}{l}.066 \\
(.298)\end{array}$ & .833 & 1.201 & $\begin{array}{c}-.124: \\
(-5.412)\end{array}$ & $\begin{array}{l}-.096: \\
(-4.571)\end{array}$ & .433 & 1.201 \\
\hline Age & $\begin{array}{l}0.23^{*} \\
(.930)\end{array}$ & $\begin{array}{c}.030 \\
(1.547) \\
\end{array}$ & .781 & 1.281 & $\begin{array}{l}.003: \\
(-.113)\end{array}$ & $\begin{array}{l}-.005: \\
(.223)\end{array}$ & .781 & 1.280 \\
\hline Education & $\begin{array}{l}0.25^{*} \\
(.817)\end{array}$ & $\begin{array}{l}-.009 \\
(-.373)\end{array}$ & .500 & 1.999 & $\begin{array}{c}.050: \\
(1.677)\end{array}$ & $\begin{array}{l}.041: \\
(1.500)\end{array}$ & .500 & 1.999 \\
\hline Position & $\begin{array}{c}-.051^{*} \\
(-2.345)\end{array}$ & $\begin{array}{c}-023 \\
(-11.174)\end{array}$ & .965 & 1.036 & $\begin{array}{c}-.046: \\
(2.155)\end{array}$ & $\begin{array}{l}-.060: \\
(3.063)\end{array}$ & .965 & 1.036 \\
\hline Rank & $\begin{array}{c}.074: \\
(2.864)\end{array}$ & $\begin{array}{c}-.073: \\
(-1.319)\end{array}$ & .688 & 1.454 & $\begin{array}{c}.121: \\
(4.766)\end{array}$ & $\begin{array}{l}-.093: \\
(3.996)\end{array}$ & .689 & 1.452 \\
\hline Area & $\begin{array}{l}-.094^{*} \\
(-3.108\end{array}$ & $\begin{array}{l}.056 \\
(2.673)\end{array}$ & .496 & 2.01 & $\begin{array}{c}-.039 \\
(-1.312)\end{array}$ & $\begin{array}{l}.003: \\
(-.125)\end{array}$ & .495 & 2.018 \\
\hline HR compliment & & $\begin{array}{l}-.058^{*} \\
(-2.355)\end{array}$ & .481 & 2.079 & & $\begin{array}{l}-.093: \\
(3.349)\end{array}$ & .481 & 2.079 \\
\hline Communication & & $\begin{array}{l}.132: \\
(4.364)\end{array}$ & .330 & 3.033 & & $\begin{array}{l}-.101: \\
(3.030)\end{array}$ & .330 & 3.030 \\
\hline Trust & & $\begin{array}{l}-.308: \\
(9.748)\end{array}$ & .303 & 1.305 & & $\begin{array}{l}-.257: \\
(7.339)\end{array}$ & .303 & 1.440 \\
\hline Stress & & $\begin{array}{l}-.116: \\
(-6.441)\end{array}$ & .927 & 1.079 & & $\begin{array}{c}.213: \\
(10.683)\end{array}$ & .927 & 1.128 \\
\hline Ad. $R^{2}$ & .028 & & \multicolumn{2}{|c|}{.365} & .058 & & .224 & \\
\hline $\mathrm{F}$ & 11.0772: & & \multicolumn{2}{|c|}{ 121.550: } & 22.758: & \multicolumn{3}{|c|}{ 61.641: } \\
\hline Note: $\mathbf{P}(0.01)$. & $0.05)$ & & & & & & & \\
\hline
\end{tabular}


Third, to improve job satisfaction, recognition of employees in HR compliment, communication, and trust need improvement. To increase HR compliment, management needs to make the employees recognize that their company is complimenting superb HR, has clear HRD vision, emphasizes the importance of HR, and seeks diverse HRD training method. To increase communication, management needs to make the employee recognize that their company is sharing details on company circumstances to the employee, the employee can suggest opinion freely to supervisor, and communicate well with a coworker. To increase trust, management needs to make the employee recognize that they can trust each other in the workplace, their evaluation and compensation are fair, and they can trust and follow company management. However, as stress shows conflict results in a negative influence on job satisfaction, yet positive on organizational commitment. Managing stress needs sensitivity about employee's feeling about current development and promotion fairness, feeling tired on the job, and tension at work.

\section{Limitation and Future Studies}

First, this study measures HR practice whether the company pursues one or has such a policy or system in place. This can only give limited implications. The results of the first hypothesis support bridging the research gap in the literature. Therefore, considering more detail type or degree of practice needs to be analyzed in a future study. Also, four out of nine HR practices showed data, which were excluded, like work 5 days a week, retirement policy, retirement support policy, and employee representative groups.

Second, this study analyzes HR practices and financial results in a collinear time point. Influence occurs with the time difference, therefore in future study the time gap needs to be considered between HR practice and financial results. Also, there is a possibility that financial improvement makes possible for the company to offer diverse HR practices. Third, there are still unsolved explanations between relationships and this implies that a black box between additional variance analysis is needed. Fourth, in this study, the analysis of job satisfaction and organizational commitment included only four employee attitudes about job and organization, and job satisfaction and organizational commitment were measured as an overall aspect. Therefore, in future research, additional variables and multiple aspects are needed. Lastly, a dramatic frequency difference in 5-day-a-week work, retirement policy, retirement support policy, and employee representative group was shown in study. Future studies might consider improving the data balance.

\section{References}

Ali, I., Rehman, K.U., Ali, S.I., Yousaf, J., \& Zia, M. (2010). Corporate social responsibility influences, employee commitment and organizational performance. African Journal of Business Management, 4(13), 2796-2801.

Ayuso, \& Navarrete-Báez, F. E. (2018). How does entrepreneurial and international orientation influence SMEs' commitment to sustainable development? Empirical evidence from Spain and Mexico. Corporate Social Responsibility and Environmental Management, 25(21), 80-94.

Bakotić, D. (2016). Relationship between job satisfaction and organisational performance. Economic Research-Ekonomska Istraživanja, 29(1), 118-130.

Banker, R.D., Konstans, C., \& Mashruwala, R. (2000). A contextual study of links between employee satisfaction, employee turnover, customer satisfaction and financial performance. The University of Texas at Dallas, Dallas, TX,

Brown, K.A., \& Mitchell, T.R. (1993). Organizational obstacles: Links with financial performance, customer satisfaction, and job satisfaction in a service environment. Human Relations, 46(6), 725-757.

Chae, S.I. (2017). A Study on Effects on Management Performance of SMEs Affected by Outsourcing Partner Ability and Partnership. Journal of the Korea Association of Business Education, 32(2), 117-140.

Chi, C.G., \& Gursoy, D. (2009). Employee satisfaction, customer satisfaction, and financial performance: An empirical examination. International Journal of Hospitality Management, 28(2), 245-253.

Chiu, S.-H., \& Lin, T.-Y. (2019). Evaluation of Regional Knowledge Innovation System in China: An Economic Framework Based on Dynamic Slacks-based Approach. Journal of Asian Finance, Economics and Business, 6(3), 141-149. https://doi. org/10.13106/jafeb.2019.vol6.no3.141

Cho, K.S., \& Hwang, J.J. (2017). The Impact of Financing Behavior on the Korean SME's Performance and Efficiency: Focusing on the Stage of the Growth Cycle. Korean Business Education Review, 29(5), 320-339. https://doi.org/10.23839/ kabe.2017.32.6.365.

Chun, J.S., Shin, Y., Choi, J.N., \& Kim, M.S. (2013). How does corporate ethics contribute to firm financial performance? The mediating role of collective organizational commitment and organizational citizenship behavior. Journal of Management, 39(4), 853-877.

Chung, D.Y., Yoo, J.H., \& Kim, C.K. (2014). Impact of networking by small business entrepreneurs and mediating effects of the effectiveness of networking on corporate performance. Journal of Business Education Research, 29(5), 147-166.

Gakovic, A., \& Tetrick, L.E. (2003). Perceived organizational support and work status: a comparison of the employment 
relationships of part-time and full-time employees attending university classes. Journal of Organizational Behavior: The International Journal of Industrial, Occupational and Organizational Psychology and Behavior, 24(5), 649-666.

Guest, D.E., Michie, J., Conway, N., \& Sheehan, M. (2003). Human resource management and corporate performance in the UK. British Journal of Industrial Relations, 41(2), 291-314.

Higgs, C.J., \& Hill, T. (2019). The role that small and mediumsized enterprises play in sustainable development and the green economy in the waste sector, South Africa. Business Strategy \& Development, 2(1), 25-31.

Huselid, M.A. (1995). The impact of human resource management practices on turnover, productivity, and corporate financial performance. Academy of Management Journal, 38(3), 635672.

Jansson, J., Nilsson, J., Modig, F., \& Hed Vall, G. (2017). Commitment to sustainability in small and medium-sized enterprises: The influence of strategic orientations and management values. Business Strategy and the Environment, 26(1), 69-83.

Kim, J. D. (2014). Effect Collaborative Activities of Large Enterprise on Performance of SMEs in Supply Chain. Korean Business Education Review, 29(4), 365-389.

Klewitz, J., \& Hansen, E.G. (2014). Sustainability-oriented innovation of SMEs: a systematic review. Journal of Cleaner Production, 65, 57-75.

Lee, K.-H., Herold, D.M., \& Yu, A.-i. (2016). Small and medium enterprises and corporate social responsibility practice: A Swedish perspective. Corporate Social Responsibility and Environmental Management, 23(2), 88-99.

Lucato, W.C., Costa, E.M., \& de Oliveira Neto, G.C. (2017). The environmental performance of SMEs in the Brazilian textile industry and the relationship with their financial performance. Journal of environmental management, 203, 550-556.

Meyer, J.P., \& Allen, N.J. (1991). A three-component conceptualization of organizational commitment. Human Resource Management Review, 1(1), 61-89.

Park, G.S. (2014). A Study on the Relationships among Strategy Types, Organizational Culture and Performance in Medium and Small Firms:. Korean Business Education Review, 29(5), 320-339.

Park, K.H., \& Kwon, H.S. (2002). An empirical study on the relationship of the important factors determining the performance of organization on the costs of training and development in Korean firm. The Journal of Small Business Innovation, 24(3), 159-197.

Schneider, B., Hanges, P.J., Smith, D.B., \& Salvaggio, A.N. (2003). Which comes first: employee attitudes or organizational financial and market performance? Journal of Applied Psychology, 88(5), 836-851. https://doi.org/10.1037/00219010.88.5.836

Sels, L., De Winne, S., Delmotte, J., Maes, J., Faems, D., \& Forrier, A. (2006). Linking HRM and small business performance: An examination of the impact of HRM intensity on the productivity and financial performance of small businesses. Small Business Economics, 26(1), 83-101.

Son, S., (2018). A Study on the Relations among Transformational Leadership of CEO, Justice and Interactive Control of PMS, and Organizational Performances: Working with 1st business Survey Data, and 2nd Archival Data. Korea Management Review, 47(5). https://doi.org/10.17287/kmr.2018.47.5.1139

Xu, K., \& Hitt, M.A. (2020). The international expansion of family firms: The moderating role of internal financial slack and external capital availability. Asia Pacific Journal of Management, 37(1), 127-153. DOI: 10.1007/s10490-018-9593-9 